\title{
Doctor of Law
}

National Cancer Institute

\section{Source}

National Cancer Institute. Doctor of Law. NCI Thesaurus. Code C71361.

A professional doctorate typically awarded by an accredited U.S. law school after successfully completing three years of post-graduate law study. Generally, a 4-year undergraduate degree is required to be eligible for entry into a JD program. 